Published in final edited form as:

Cancer Transl Med. 2018 ; 4(3): 70-74. doi:10.4103/ctm.ctm_22_18.

\title{
Senescence and Cancer
}

Sulin Zeng ${ }^{1,2}$, Wen H. Shen ${ }^{2}$, and Li Liu ${ }^{1}$

${ }^{1}$ Department of Microbiology, Institute of Basic Medical Sciences, Chinese Academy of Medical Sciences and School of Basic Medicine, Peking Union Medical College, Beijing, China;

${ }^{2}$ Department of Radiation Oncology, Weill Medical College of Cornell University, New York, NY, USA

\section{Abstract}

Senescence is a double-edged sword that can function in opposite directions. It is a potential mechanism for a cell to avoid malignant transformation. However, senescence can also promote cancer development by altering the cellular microenvironment through a senescence-associated secretory phenotype (SASP). At least, three types of cellular stress such as activation of oncogenes, loss of tumor suppressor genes, and chemo/radiotherapy can induce cell senescence. Oncogene-induced senescence can be intertwiningly associated with the replicative senescence. Early-stage senescence may protect cell from transformation, while prolonged senescence often promotes cancer development. This review will focus on the characteristics of senescence, discuss the regulation of senescence during cancer development, and highlight the complexity of senescence that makes cancer treatment challenging.

\section{Keywords}

Cancer; chemotherapy; radiotherapy; senescence

\section{INTRODUCTION}

In 1965, Leonard Hayflick found that normal cells could not proliferate endlessly after doubling dozens of times. These cells gradually and eventually halted from dividing and became enlarged with many cytosolic granules. This phenomenon has been named "senescence". ${ }^{1}$ The nondividing senescent cells remained viable, however, failed to respond to growth and death stimuli. The molecular characteristics of senescent cells usually include upregulation of cell-cycle inhibitors such as $\mathrm{p} 21$ and/or p16, ${ }^{2}$ positive staining of senescence-associated $\beta$-galactosidase (SA- $\beta$-gal), ${ }^{2}$ formation of senescence-associated heterochromatin foci (SAHF), ${ }^{3}$ and the induction of senescence-associated DNA damage. ${ }^{4}$ However, senescent cells usually do not obtain all the characteristics mentioned above.

\footnotetext{
Address for correspondence: Prof. Li Liu, Department of Microbiology, Institute of Basic Medical Sciences, Chinese Academy of Medical Sciences and School of Basic Medicine, Peking Union Medical College, Beijing 100005, China. lliu@ pumc.edu.cn; Prof. Wen H. Shen, Department of Radiation Oncology, Weill Medical College of Cornell University, New York, NY 10065, USA. wes2007@med.cornell.edu.

Conflicts of interest

There are no conflicts of interest.
} 
Senescent cells are a type of cells with irreversible cell-cycle arrest and apoptotic resistance. There are many types of senescence: replicative senescence, oncogene-induced senescence such as, and therapy-induced senescence. Oncogene-induced senescence can be viewed as a mechanism for an organism to prevent tumorigenesis. However, senescence occurring during cancer treatment may ambiguously impact tumor response, which unravels the complexity of senescence in vivo and also raises a question about the irreversibility of senescence. ${ }^{5}$ This review clarifies the characteristics and regulation of senescence and discusses the complex role of senescence in cancer treatment.

\section{THE BIOMARKERS OF SENESCENCE}

\section{Senescence-associated $\beta$-galactosidase}

Dimri et al. ${ }^{6}$ discovered in 1995 that senescent fibroblast cells turned blue at $\mathrm{pH} 6.0$ when 5bromo-4-chloro-3-indolyl- $\beta$-D-galactoside (X-gal) was added, while quiescent, terminally differentiated or immortal cells did not possess such a feature. Since then, $\beta$-gal assay has become a classical method to detect cellular senescence. B-gal can hydrolyze X-gal into galactose and 5-bromo-4-chloro-3-hydroxyindole, which dimerizes and oxidizes to a blue product, 5,5'-dibromo-4,4'-dichloro-indigo. ${ }^{7}$ However, it was unknown why senescent cells express a high level of $\beta$-gal until Lee's report. ${ }^{8}$ Lee et al. ${ }^{8}$ demonstrated that SA- $\beta$-gal was expressed from the gene of lysosomal $\beta$-gal (GLB1). Fibroblasts with mutant GLB1 had low lysosomal $\beta$-gal activity at late passage even though they underwent replicative senescence. When the GLB1 gene was knocked down, the activity of $\beta$-gal of senescent cells was reduced. The authors thus concluded that SA- $\beta$-gal activity could reflect the expression level of lysosomal $\beta$-gal protein in senescent cells.

\section{Senescence-associated heterochromatin foci}

When cells are stained with $4^{\prime}$,6-diamidino-2-phenylindole (DAPI), a fluorescent dye that binds strongly to A-T rich regions in DNA, senescent cells typically display one large nucleolus with punctate DNA foci known as SAHF. ${ }^{9}$ These DAPI-staining punctate SAHF foci represent heterochromatin regions that are usually bound with heterochromatin proteins such as heterochromatin protein 1 (HP1) and hypoacetylated histones, ${ }^{10}$ which may explain the altered gene expression when cells undergo senescence. Activated retinoblastoma protein (pRb) localizes to these foci and help remodel chromatin to form SAFH foci. ${ }^{11}$

\section{Senescence-associated secretory phenotype}

When performing a genome-wide small hairpin RNA screen to identify the genes required for blocking $\mathrm{BRAF}^{\mathrm{V} 600 \mathrm{E}}$-mediated cell proliferation, Wajapeyee et al. ${ }^{12}$ detected a secreted protein named insulin growth factor binding protein. ${ }^{7}$ This protein can inhibit the proliferation of melanoma cells through the BRAF-MEK-ERK signaling pathway, revealing a secretory mechanism for senescent cells to avoid tumorigenesis. Besides growth factors, senescent cells can secrete cytokines and enzymes such as interleukin (IL)-1, IL-6, and IL-8 ${ }^{13}$ and metalloproteinase. ${ }^{14}$ These secreted factors can exert diverse functions. On one hand, specific components of senescence-associated secretory phenotype (SASP) such as IGFBP7, IL-6, and IL-8 may suppress tumor growth; ${ }^{15}$ on the other hand, enzymatic 
components such as matrix metalloproteinase-3 (MMP-3) can promote tumor invasion and metastasis. ${ }^{16}$

\section{THE CAUSES OF SENESCENCE}

\section{Replicative senescence}

Primary cells cannot divide permanently in culture. They usually undergo a permanent growth arrest and stop responding to external stimuli such as changes of the cultural condition. ${ }^{1}$ Here is a question: what limits their proliferation. Telomere shortening may be one of the main causes. Telomere is a complex structure comprised repetitive DNA with associated proteins that caps the chromosomal ends and protects them from degradation or fusion during DNA-repair process. ${ }^{17}$ Mutation of the ever shorter telomere 1 gene in yeast caused gradual loss of telomere sequence and resulted in a phenotype similar to senescence. ${ }^{18}$ Later study by Harley et al. ${ }^{19}$ showed that the number and length of telomeres were negatively correlated with the passage times of the cells. When human telomerase reverse transcriptase was supplemented to the telomerase-null fibroblasts, the telomeres of these cells became longer, and the cells division turned quicker with normal karyotype. These telomerase-supplemented fibroblasts could passage more than 20 times and displayed less $\beta$ gal staining than that of the telomerase-null fibroblasts. ${ }^{20}$ All of the above evidence indicates that telomere shortening is one of the main causes for replicative senescence.

Replicative senescence possesses classic features of DNA double-strand breaks (DSBs), with activated ataxia telangiectasia mutated (ATM), and/or ATM and RAD3-related (ATR) and their respective mediators, checkpoint kinase 2 (CHK2) and CHK1. d'Adda di Fagagna et al. ${ }^{21}$ found that damaged telomeres were associated with these DNA damage response proteins. When microinjected with combinations of plasmids expressing kinase-dead ATM (ATM-KD), ATR-KD, CHK1-KD, and CHK2-KD, senescent BJ cells could enter S phase to undergo proliferation, ${ }^{21}$ indicating that damaged telomeres induced senescence by activating the DNA damage checkpoint pathways.

\section{Oncogene-induced senescence}

When transfected with oncogene such as SV40 large T or mutant hRAS, FS-2 cells (a diploid, human neonatal fibroblasts) preferentially entered cellular senescence but not transformation, ${ }^{22}$ although the study by Serrano et al. ${ }^{23}$ demonstrated that RAS could transform most of the mouse cells. In human primary cells, senescence can be induced by the upregulation of both $\mathrm{p} 53$ and p 16 by oncogene, while inactivation of p53 or p16 can prevent cellular senescence. This demonstrates that the ectopic expression of oncogenes can induce senescence.

Similar to replicative senescence, oncogene-induced senescence also activates DNA damage response pathway. Overexpression of proto-oncogene serine/threonine-protein kinase mos (mos), cell division control protein 6 homolog (cdc6), or cyclin E activated the DNA damage checkpoint and induced senescence. ${ }^{24}$ In precancerous lesions, robust activation of the DSB checkpoint is directly correlated with senescence. However, progression to carcinoma often 
abrogates this relationship, suggesting that, such as apoptosis, senescence may provide a barrier for tumor progression. ${ }^{24}$

In addition to the activation of oncogenes, loss of tumor suppressor genes can also induce senescence. For example, acute inactivation of PTEN induced p53-mediated cellular senescence. ${ }^{25}$ This PTEN-loss-induced cellular senescence (PICS) was further demonstrated to be distinct from oncogene-induced senescence. This special type of senescence occurred in the absence of cellular proliferation and DNA damage checkpoint response and can be targeted for cancer therapy. Specifically, inhibition of tumorigenesis was achieved by pharmacological inhibition of PTEN. ${ }^{26}$ Interestingly, PTEN-null senescent cells secreted immunosuppressive cytokines through the Jak2/Stat3 pathway, pharmacological inhibition of which led to an antitumor immune response that enhances the efficacy of chemotherapy. ${ }^{27}$ These results suggest that PTEN-deficient senescent tumor cells drive an immunosuppressive tumor microenvironment through SASP and that blocking the mediators and effectors of PICS may evoke antitumor immune surveillance.

\section{Therapy-induced senescence}

Cancer is a cluster of cells that acquire abnormal survival and growth behaviors.

Chemotherapy or radiation therapy represents common strategies to kill these cancerous cells. However, these treatments inevitably confer toxicity and unwanted side effects. Fortunately, scientists have found that low-dose radiotherapy or chemotherapy can reduce side effect by promoting senescence in cancer cells.

Bleomycin is an anticancer drug that induces DNA strand breaks. Fibroblast cells treated with bleomycin exhibited DNA double-strand breakage but not apoptosis. ${ }^{28}$ Cells then entered an extended cell-cycle arrest for at least 30 days, accompanied by the upregulation of p53/p21 and p16 in the early and late stage respectively. Thus, chemical agents that cause DNA strand breaks are sufficient to induce cellular senescence. Wang et al. ${ }^{29}$ have shown that cisplatin could induce CNE1 cells, a nasopharyngeal carcinoma cell line, to undergo senescence-like cell-cycle arrest with typical morphological changes and elevated signals of $\beta$-gal. Moreover, a higher proportion of senescent cells were associated with lower doses of cisplatin. Later studies found that other chemical drugs such as hydroxyurea, ${ }^{30}$ doxorubicin, 31 camptothecin $^{32}$ and 5-bromodeoxyuridine ${ }^{33}$ can also induce cell senescence. These data indicate that DNA-damaging agent can induce senescence not only in primary cells but also in cancerous cells.

Like chemical drugs, radiation therapy can also elicit cell senescence. When exposed to $>4$ Gy gamma ionizing radiation, normal fibroblasts underwent $\mathrm{G} 1$ arrest for longer than 3 weeks. Exposure to low-dose radiation caused G1 arrest in most cells although a few proceeded to DNA replication. ${ }^{29}$

\section{SIGNALING PATHWAYS INVOLVED IN CELL SENESCENCE}

Cellular events such as telomere shortening, ${ }^{20}$ oncogene activation, ${ }^{24}$ or chemo/ radiotherapy ${ }^{4,28-33}$ can induce cell senescence mainly through the activation of p53 or pRb. Mutation of p53 in embryonic fibroblasts prevents senescence and leads to uncontrolled 
cells proliferation. ${ }^{34}$ Similarly, pRb mutation in a combination of inactivation of p107 and p130 can inhibit cellular senescence. ${ }^{35,36}$ It is believed that both p53 and pRb are important mediators of cellular senescence although they are involved in different cellular signaling pathways.

Cellular stress can activate p53 through diverse mechanisms. For example, telomere breakage or DNA damaging agents can induce DNA damage response, manifested by activation of ATM and ATR and subsequent activation of their respective mediators CHK2 and CHK1. Activated CHK2 or CHK1 can phosphorylate p53 and latter induces DNA damage repair or initiates cell senescence. ${ }^{37}$ Activated p53 induces the transcription of p21, which blocks cell-cycle progression by inhibiting CDK2. ${ }^{38} \mathrm{MDM} 2$ is an E3 ligase that binds p53 to cause its degradation while blocking this pathway by p14ARF represents another mechanism of p53 activation. ${ }^{39}$

$\mathrm{pRb}$ is regulated not only by the $\mathrm{p} 53-\mathrm{p} 21-\mathrm{CDK} 2$ pathway $^{40}$ but also by $\mathrm{p} 16$-related pathways, especially in epithelial cells. p16, an inhibitor of the cyclinD-CDK4/6 complex, is not expressed in normal adult tissues ${ }^{41}$ but highly expressed in senescent cells. ${ }^{42}$ p16 is one of the most frequently mutant genes in human cancer, ${ }^{43}$ deletion of which results in $\mathrm{pRb}$ inactivation and cell-cycle progression from $\mathrm{G} 1$ to $\mathrm{S}$ phase. Therefore, $\mathrm{p} 16$ and $\mathrm{pRb}$ form a tumor suppressor pathway and their mutations often occur in a mutually exclusive manner. ${ }^{44}$ $\mathrm{p} 53$ and $\mathrm{pRb}$ are also functionally interrelated. The $\mathrm{p} 16^{\mathrm{INK} 4 \mathrm{a}}$ and $\mathrm{p} 14^{\mathrm{ARF}}$ genes are located at the same locus with two shared exons. ${ }^{45}$ Mutations of $\mathrm{p} 16^{\mathrm{INK} 4 \mathrm{a}}$ usually inactivates these two genes, leading to simultaneous inhibition of both $\mathrm{p} 53$ and pRb. Another functional link between $\mathrm{p} 53$ and $\mathrm{pRb}$ has been demonstrated by a study showing that E2F-1, a transcription factor that is normally inhibited by $\mathrm{pRb}$, can activate $\mathrm{p} 53$ by promoting the transcription of p14 $\mathrm{ARF} .46$

Cellular senescence can also be induced by other mechanisms in a p53- and pRbindependent manner. Knockdown of the histone acetyltransferase p300 led to the global hypoacetylation of histones $\mathrm{H} 3$ and $\mathrm{H} 4$, formation of heterochromatin foci during $\mathrm{S}$ phase and production of lower-speed replication forks. Despite the lack of DNA damage checkpoint activation, cells were indeed arrested in G2/M phase and underwent senescence. Meanwhile, downregulation of p53 and p16 showed no influence on senescence induced by knockdown of $\mathrm{p} 300$, indicating that $\mathrm{p} 300$ regulates senescence in a p53- and p16independent manner. ${ }^{47}$

\section{THE REVERSE OF SENESCENCE}

In senescent BJ cells, on inactivation of ATM, ATR, CHK1, and CHK2, 17\% of the cells reentered S phase, ${ }^{21}$ which questions the irreversibility of senescence. Dirac and Bernards 34 found that the suppression of p53 enabled a small proportion (about $0.5 \%-1 \%$ ) of senescent embryonic fibroblasts to reenter the cell cycle. They used time-lapse photomicrographs to validate that these cells were originated from senescent cells. However, Kang et al. ${ }^{48}$ suggested that senescence is reversible only in the early stage of senescence establishment, likely through the inactivation of p53 and pRb. These changes can no longer reverse 
senescence once the senescent state is formed and stabilized. They induced senescence by transducing E2 protein of bovine papillomavirus 1 and found that $\mathrm{pRb}$ inactivation by HPV E7 oncoprotein could reverse senescence in the early stage, but failed to do so 5 days after senescence establishment. Clearly, more research is needed to clarify the reversibility of senescence.

In addition to the reversibility of senescence, the secretory phenotype of senescence adds another layer of complexity in treating cancers. Condition culture media from senescent malignant pleural mesothelioma cells induced epithelial-to-mesenchymal transition (EMT) and resistance to chemotherapy due to high levels of secreted aldehyde dehydrogenase. ${ }^{49}$ Laberge et al. ${ }^{50}$ found that senescent fibroblasts could trigger EMT in surrounding epithelial cells. Collectively, these data suggest that senescent cells can change the tumor microenvironment and facilitate invasion, metastasis, and resistance to therapies.

\section{CLINICAL APPLICATION OF SENESCENCE}

Cytotoxic agents are often used in high doses to eliminate cancer cells, which unfortunately can give rise to severe side effects on normal cells. Alternatively, lower doses of the same agents may induce senescence in cancer cells ${ }^{51}$ and avoid side effects on normal cells. Indeed, the induction of senescence is a popular strategy in cancer treatment, and ongoing clinical applications of such strategy include hydroxyurea, ${ }^{30}$ doxorubicin, ${ }^{31}$ camptothecin ${ }^{32}$ and 5-bromodeoxyuridine. ${ }^{33}$ Moreover, senescence can be induced by extracellular or intracellular stresses even in cancer cells with mutant p53 and/or pRb, suggesting that there are novel mechanisms independent of $\mathrm{p} 53$ and $\mathrm{pRb} .{ }^{43,52,53}$

Although senescence forms a barrier to tumorigenesis and senescent cells often remain dormant in vivo for months and even for years, once these dormant cancer cells reenter the cell cycle, tumorigenesis can resume, and cancer can relapse. ${ }^{54}$ Meanwhile, senescent cells can secrete proteins such as MMP-3 to promote tumor invasion and metastasis. ${ }^{55}$ This phenomenon indicates that senescence itself can be detrimental and serve as a target for therapy. Effective strategies to eradicate these harmful senescent cells are under research.

Baar et al. ${ }^{56}$ found that FOXO4 is overexpressed in senescent cells. They, then synthesize a D-retro-inverso modified FOXO4 peptide to release p53, which interacts with FOXO4 in senescent cells and to induce senescent cells to undergo apoptosis in a p53-dependent manner. Oncolytic measles vaccine viruses are also used to eradicate senescent cells. ${ }^{57}$ Treated with EB 1089, a vitamin D3 analog before radiotherapy, cells undergo apoptosis and skipped senescence. ${ }^{58}$ These researches above confer a possibility to extinguish senescent cells occurring during chemo/radiotherapy.

\section{CONCLUSION}

Senescent cells are withdrawn from cell-cycle permanently and can be cleared by macrophages, neutrophils, or natural killer cells. ${ }^{59,60}$ However, they can maintain their senescent status for years and accumulate with age, ${ }^{56}$ which confers a risk or reentering the cell cycle and promoting oncogenesis. On the other hand, senescence serves as a natural barrier to uncontrolled cell growth and malignant transformation. These miscellaneous roles 
of senescence pose a significant challenge to our efforts in targeting senescence-related pathways to treat cancers. More intensive research is needed to better understand the molecular mechanisms underlying the establishment, maintenance, and blockage of senescence, to clarify its reversibility, and to develop novel senescence-targeted strategies in anticancer treatment.

\section{Financial support and sponsorship}

The study is supported by grants from Chinese Academy of Medical Sciences Initiative for Innovative Medicine (2017-I2M-3-007), and National key research and development plan of Ministry of Sciences and Technology (2016YFC1202400). Our research is also supported by the National Institutes of Health grant (R01GM100478) and the Irma T. Hirschl/Monique Weill-Caulier Trust.

\section{REFERENCES}

1. Hayflick L The limited in vitro lifetime of human diploid cell strains. Exp Cell Res 1965; 37: 61436. [PubMed: 14315085]

2. He L, Chen Y, Feng J, Sun W, Li S, Ou M, Tang L. Cellular senescence regulated by SWI/SNF complex subunits through p53/p21 and p16/pRB pathway. Int J Biochem Cell Biol 2017; 90: 29-37. [PubMed: 28716547]

3. Yamauchi M, Shibata A, Suzuki K, Suzuki M, Niimi A, Kondo H, Miura M, Hirakawa M, Tsujita K, Yamashita S, Matsuda N. Regulation of pairing between broken DNA-containing chromatin regions by Ku80, DNA-PKcs, ATM, and 53BP1. Sci Rep 2017; 7: 41812. [PubMed: 28155885]

4. Kim HN, Chang J, Shao L, Han L, Iyer S, Manolagas SC, O’Brien CA, Jilka RL, Zhou D, Almeida M. DNA damage and senescence in osteoprogenitors expressing OsÅ 1 may cause their decrease with age. Aging Cell 2017; 16 (4): 693-703. [PubMed: 28401730]

5. Chakradeo S, Elmore LW, Gewirtz DA. Is senescence reversible? Curr Drug Targets 2016; 17 (4): 460-6. [PubMed: 26302802]

6. Dimri GP, Lee XH, Basile G, Acosta M, Scott C, Roskelley C, Medrano EE, Linskensi M, Rubeljii I, Pereira-Smithii O, Peacocket M,Campisi J. A biomarker that identifies senescent human-cells in culture and in aging skin in vivo. Proc Natl Acad Sci U S A 1995; 92 (20): 9363-7. [PubMed: 7568133]

7. Horwitz JP, Chua J, Curby RJ, Tomson AJ, Darooge Ma, Fisher BE, Mauricio J, Klundt I. Substrates for cytochemical demonstration of enzyme activity. I. Some substituted 3-indolyl-beta-dglycopyranosides. J Med Chem 1964; 7: 574-5. [PubMed: 14221156]

8. Lee BY, Han JA, Im JS, Morrone A, Johung K, Goodwin EC, Kleijer WJ, DiMaio D, Hwang ES. Senescence-associated beta-galactosidase is lysosomal beta-galactosidase. Aging Cell 2006; 5 (2): 187-95. [PubMed: 16626397]

9. Narita M, Nũnez S, Heard E, Narita M, Lin AW, Hearn SA, Spector DL, Hannon GJ, Lowe SW. Rbmediated heterochromatin formation and silencing of E2F target genes during cellular senescence. Cell 2003; 113 (6): 703-16. [PubMed: 12809602]

10. Narita M, Narita M, Krizhanovsky V, Nuez S, Chicas A, Hearn SA, Myers MP, Lowe SW. A novel role for high-mobility group A proteins in cellular senescence and heterochromatin formation. Cell 2006; 126 (3): 503-14. [PubMed: 16901784]

11. Ye X, Zerlanko B, Zhang R, Somaiah N, Lipinski M, Salomoni P, Adams PD. Definition of pRBand p53-dependent and -independent steps in HIRA/ASF1a-mediated formation of senescenceassociated heterochromatin foci. Mol Cell Biol 2007; 27 (7): 2452-65. [PubMed: 17242198]

12. Wajapeyee N, Serra RW, Zhu X, Mahalingam M, Green MR. Oncogenic BRAF induces senescence and apoptosis through pathways mediated by the secreted protein IGFBP7. Cell 2008; 132 (3): 363-74. [PubMed: 18267069]

13. Copp JP, Patil CK, Rodier F, Sun Y, Mu.oz DP, Goldstein J, Nelson PS, Desprez PY, Campisi J. Senescence-associated secretory phenotypes reveal cell-nonautonomous functions of oncogenic RAS and the p53 tumor suppressor. PLoS Biol 2008; 6 (12): 2853-68. [PubMed: 19053174] 
14. Coppe JP, Desprez PY, Krtolica A, Campisi J. The senescence-associated secretory phenotype: the dark side of tumor suppression. Annu Rev Pathol 2010; 5: 99-118. [PubMed: 20078217]

15. Acosta JC, Banito A, Wuestefeld T, Georgilis A, Janich P, Morton JP, Athineos D, Kang TW, Lasitschka F, Andrulis M, Pascual G, Morris KJ, Khan S, Jin H, Dharmalingam G, Snijders AP, Carroll T, Capper D, Pritchard C, Inman GJ, Longerich T, Sansom OJ, Benitah SA, Zender L, Gil J. A complex secretory program orchestrated by the inflammasome controls paracrine senescence. Nat Cell Biol 2013; 15 (8): 978-90. [PubMed: 23770676]

16. Lasry A, Ben-Neriah Y. Senescence-associated inflammatory responses: aging and cancer perspectives. Trends Immunol 2015; 36 (4): 217-28. [PubMed: 25801910]

17. d'Adda di Fagagna F, Teo SH, Jackson SP. Functional links between telomeres and proteins of the DNA-damage response. Genes Dev 2004; 18 (15): 1781-99. [PubMed: 15289453]

18. Lundblad V, Szostak JW. A mutant with a defect in telomere elongation leads to senescence in yeast. Cell 1989; 57 (4): 633-43. [PubMed: 2655926]

19. Harley CB, Futcher AB, Greider CW. Telomeres shorten during ageing of human fibroblasts. Nature 1990; 345 (6274): 458-60. [PubMed: 2342578]

20. Bodnar AG, Ouellette M, Frolkis M, Holt SE, Chiu CP, Morin GB, Harley CB, Shay JW, Lichtsteiner S, Wright WE. Extension of life-span by introduction of telomerase into normal human cells. Science 1998; 279 (5349): 349-52. [PubMed: 9454332]

21. d'Adda di Fagagna F, Reaper PM, Clay-Farrace L, Fiegler H, Carr P, Von Zglinicki T, Saretzki G, Carter NP, Jackson SP. A DNA damage checkpoint response in telomere-initiated senescence. Nature 2003; 426 (6963): 194-8. [PubMed: 14608368]

22. O'Brien W, Stenman G, Sager R. Suppression of tumor growth by senescence in virally transformed human fibroblasts. Proc Natl Acad Sci U S A 1986; 83 (22): 8659-63. [PubMed: 3022300]

23. Serrano M, Lin AW, McCurrach ME, Beach D, Lowe SW. Oncogenic ras provokes premature cell senescence associated with accumulation of p53 and p16INK4a. Cell 1997; 88 (5): 593-602. [PubMed: 9054499]

24. Bartkova J, Rezaei N, Liontos M, Karakaidos P, Kletsas D, Issaeva N, Vassiliou LV, Kolettas E, Niforou K, Zoumpourlis VC, Takaoka M, Nakagawa H, Tort F, Fugger K, Johansson F, Sehested M, Andersen CL, Dyrskjot L, rntoft T, Lukas J, Kittas C, Helleday T, Halazonetis TD, Bartek J, Gorgoulis VG. Oncogene-induced senescence is part of the tumorigenesis barrier imposed by DNA damage checkpoints. Nature 2006; 444 (7119): 633-7. [PubMed: 17136093]

25. Chen Z, Trotman LC, Shaffer D, Lin HK, Dotan ZA, Niki M, Koutcher JA, Scher HI, Ludwig T, Gerald W, Cordon-Cardo C, Pandolfi PP. Crucial role of p53-dependent cellular senescence in suppression of Pten-deficient tumorigenesis. Nature 2005; 436 (7051): 725-30. [PubMed: 16079851]

26. Alimonti A, Nardella C, Chen Z, Clohessy JG, Carracedo A, Trotman LC, Cheng K, Varmeh S, Kozma SC, Thomas G, Rosivatz E, Woscholski R, Cognetti F, Scher HI, Pandolfi PP. A novel type of cellular senescence that can be enhanced in mouse models and human tumor xenografts to suppress prostate tumorigenesis. J Clin Invest 2010; 120 (3): 681-93. [PubMed: 20197621]

27. Toso A, Revandkar A, Di Mitri D, Guccini I, Proietti M, Sarti M, Pinton S, Zhang J, Kalathur M, Civenni G, Jarrossay D, Montani E, Marini C, Garcia-Escudero R, Scanziani E, Grassi F, Pandolfi PP, Catapano CV, Alimonti A. Enhancing chemotherapy efficacy in Pten-deficient prostate tumors by activating the senescence-associated antitumor immunity. Cell Rep 2014; 9 (1): 75-89. [PubMed: 25263564]

28. Robles SJ, Adami GR. Agents that cause DNA double strand breaks lead to p16INK4a enrichment and the premature senescence of normal fibroblasts. Oncogene 1998; 16 (9): 1113-23. [PubMed: 9528853]

29. Wang X, Wong SC, Pan J, Tsao SW, Fung KH, Kwong DL, Sham JS, Nicholls JM. Evidence of cisplatin-induced senescent-like growth arrest in nasopharyngeal carcinoma cells. Cancer Res 1998; 58 (22): 5019-22. [PubMed: 9823301]

30. Park JI, Jeong JS, Han JY, Kim DI, Gao YH, Park SC, Rodgers GP, Kim IH. Hydroxyurea induces a senescence-like change of K562 human erythroleukemia cell. J Cancer Res Clin Oncol 2000; 126 (8): 455-60. [PubMed: 10961388] 
31. te Poele RH, Okorokov AL, Jardine L, Cummings J, Joel SP. DNA damage is able to induce senescence in tumor cells in vitro and in vivo. Cancer Res 2002; 62 (6): 1876-83. [PubMed: 11912168]

32. Han Z, Wei W, Dunaway S, Darnowski JW, Calabresi P, Sedivy J, Hendrickson EA, Balan KV, Pantazis P, Wyche JH. Role of p21 in apoptosis and senescence of human colon cancer cells treated with camptothecin. J Biol Chem 2002; 277 (19): 17154-60. [PubMed: 11877436]

33. Suzuki T, Minagawa S, Michishita E, Ogino H, Fujii M, Mitsui Y, Ayusawa D. Induction of senescence-associated genes by 5-bromodeoxyuridine in HeLa cells. Exp Gerontol 2001; 36 (3): 465-74. [PubMed: 11250118]

34. Dirac AM, Bernards R. Reversal of senescence in mouse fibroblasts through lentiviral suppression of p53. J Biol Chem 2003; 278 (14): 11731-4. [PubMed: 12551891]

35. Dannenberg JH, van Rossum A, Schuijff L, te Riele H. Ablation of the retinoblastoma gene family deregulates $\mathrm{G}$ (1) control causing immortalization and increased cell turnover under growthrestricting conditions. Genes Dev 2000; 14 (23): 3051-64. [PubMed: 11114893]

36. Sage J, Mulligan GJ, Attardi LD, Miller A, Chen S, Williams B, Theodorou E, Jacks T. Targeted disruption of the three Rb-related genes leads to loss of G (1) control and immortalization. Genes Dev 2000; 14 (23): 3037-50. [PubMed: 11114892]

37. Wahl GM, Carr AM. The evolution of diverse biological responses to DNA damage: insights from yeast and p53. Nat Cell Biol 2001; 3 (12): E277-86. [PubMed: 11781586]

38. Munoz-Espin D, Serrano M. Cellular senescence: from physiology to pathology. Nat Rev Mol Cell Biol 2014; 15 (7): 482-96. [PubMed: 24954210]

39. Ben-Porath I, Weinberg RA. The signals and pathways activating cellular senescence. Int J Biochem Cell Biol 2005; 37 (5): 961-76. [PubMed: 15743671]

40. Harper JW, Adami GR, Wei N, Keyomarsi K, Elledge SJ. The p21 Cdk-interacting protein Cip1 is a potent inhibitor of G1 cyclin-dependent kinases. Cell 1993; 75 (4): 805-16. [PubMed: 8242751]

41. Lowe SW, Sherr CJ. Tumor suppression by Ink4a-Arf: progress and puzzles. Curr Opin Genet Dev 2003; 13 (1): 77-83. [PubMed: 12573439]

42. Li LU, Zhao Y, Zhang H. P16INK4a upregulation mediated by TBK1 induces retinal ganglion cell senescence in ischemic injury. Cell Death Dis 2017; 8 (4): e2752. [PubMed: 28425986]

43. Rocco JW, Sidransky D. p16(MTS-1/CDKN2/INK4a) in cancer progression. Exp Cell Res 2001; 264 (1): 42-55. [PubMed: 11237522]

44. Aagaard L, Lukas J, Bartkova J, Kjerulff AA, Strauss M, Bartek J. Aberrations of p16Ink4 and retinoblastoma tumour-suppressor genes occur in distinct sub-sets of human cancer cell lines. Int $\mathrm{J}$ Cancer 1995; 61 (1): 115-20. [PubMed: 7705923]

45. Quelle DE, Zindy F, Ashmun RA, Sherr CJ. Alternative reading frames of the INK4a tumor suppressor gene encode two unrelated proteins capable of inducing cell cycle arrest. Cell 1995; 83 (6): 993-1000. [PubMed: 8521522]

46. Bates S, Phillips AC, Clark PA, Stott F, Peters G, Ludwig RL, Vousden KH. p14ARF links the tumour suppressors RB and p53. Nature 1998; 395 (6698): 124-5. [PubMed: 9744267]

47. Prieur A, Besnard E, Babled A, Lemaitre JM. p53 and p16(INK4A) independent induction of senescence by chromatin-dependent alteration of S-phase progression. Nat Commun 2011; 2: 473. [PubMed: 21915115]

48. Kang HT, Lee CJ, Seo EJ, Bahn YJ, Kim HJ, Hwang ES. Transition to an irreversible state of senescence in HeLa cells arrested by repression of HPV E6 and E7 genes. Mech Ageing Dev 2004; 125 (1): 31-40. [PubMed: 14706235]

49. Canino C, Mori F, Cambria A, Diamantini A, Germoni S, Alessandrini G, Borsellino G, Galati R, Battistini L, Blandino R, Facciolo F, Citro G, Strano S, Muti P, Blandino G, Cioce M. SASP mediates chemoresistance and tumor-initiating-activity of mesothelioma cells. Oncogene 2012; 31 (26): 3148-63. [PubMed: 22020330]

50. Laberge RM, Awad P, Campisi J, Desprez PY. Epithelial-mesenchymal transition induced by senescent fibroblasts. Cancer Microenviron 2012; 5 (1): 39-44. [PubMed: 21706180]

51. Ewald JA, Desotelle JA, Wilding G, Jarrard DF. Therapy-induced senescence in cancer. J Natl Cancer Inst 2010; 102 (20): 1536-46. [PubMed: 20858887] 
52. Chang BD, Swift ME, Shen M, Fang J, Broude EV, Roninson IB. Molecular determinants of terminal growth arrest induced in tumor cells by a chemotherapeutic agent. Proc Natl Acad Sci U S A 2002; 99 (1): 389-94. [PubMed: 11752408]

53. Chang BD, Broude EV, Dokmanovic M, Zhu H, Ruth A, Xuan Y, Kandel ES, Lausch E, Christov $\mathrm{K}$, Roninson IB. A senescence-like phenotype distinguishes tumor cells that undergo terminal proliferation arrest after exposure to anticancer agents. Cancer Res 1999; 59 (15): 3761-7. [PubMed: 10446993]

54. Gewirtz DA. Autophagy, senescence and tumor dormancy in cancer therapy. Autophagy 2009; 5 (8): 1232-4. [PubMed: 19770583]

55. Parrinello S, Coppe JP, Krtolica A, Campisi J. Stromal-epithelial interactions in aging and cancer: senescent fibroblasts alter epithelial cell differentiation. J Cell Sci 2005; 118 (Pt 3): 485-96. [PubMed: 15657080]

56. Baar MP, Brandt RM, Putavet DA, Klein JD, Derks KW, Bourgeois BR, Stryeck S, Rijksen Y, van Willigenburg H, Feijtel DA, van der Pluijm I, Essers J, van Cappellen WA, van Ijcken WF, Houtsmuller AB, Pothof J, de Bruin RW, Madl T, Hoeijmakers JH, Campisi J, de Keizer PL. Targeted apoptosis of senescent cells restores tissue homeostasis in response to chemotoxicity and aging. Cell 2017; 169 (1): 132-47.e16. [PubMed: 28340339]

57. Weiland T, Lampe J, Essmann F, Venturelli S, Berger A, Bossow S, Berchtold S, Schulze-Osthoff K, Lauer UM, Bitzer M. Enhanced killing of therapy-induced senescent tumor cells by oncolytic measles vaccine viruses. Int J Cancer 2014; 134 (1): 235-43. [PubMed: 23797800]

58. DeMasters GA, Gupta MS, Jones KR, Cabot M, Wang H, Gennings C, Park M, Bratland A, Ree $\mathrm{AH}$, Gewirtz DA. Potentiation of cell killing by fractionated radiation and suppression of proliferative recovery in MCF-7 breast tumor cells by the Vitamin D3 analog EB 1089. J Steroid Biochem Mol Biol 2004; 92 (5): 365-74. [PubMed: 15698541]

59. Xue W, Zender L, Miething C, Dickins RA, Hernando E, Krizhanovsky V, Cordon-Cardo C, Lowe $\mathrm{SW}$. Senescence and tumour clearance is triggered by p53 restoration in murine liver carcinomas. Nature 2007; 445 (7128): 656-60. [PubMed: 17251933]

60. Perez-Mancera PA, Young AR, Narita M. Inside and out: the activities of senescence in cancer. Nat Rev Cancer 2014; 14 (8): 547-58. [PubMed: 25030953] 